Reseña

\section{Ayodeji Olukoju and Daniel Castillo Hidalgo (eds.). African Seaports and Maritime Economics in Historical Perspec- tive. London, Palgrave, 2020, 239 pp. ISBN: 978-3030413996.}

Edited by Ayodeji Olukoju, Professor of History at the University of Lagos, and Daniel Castillo Hidalgo, Assistant Professor of Economic History at the University of Las Palmas de Gran Canaria, this book stands as a new and important contribution to our knowledge of African economic history.

It focuses on the historical evolution and role of African seaport networks. The importance of seaports for African economies cannot be understated. Given Africa's specialization as an exporter of raw materials, the continent's economic fortunes are often linked to fluctuations in commodity export markets (Jerven, 2011). In this regard, the maritime sector and port infrastructure play a key role.

The book was a pleasure to read and easy to follow. It has nine chapters, seven written by several different authors, complemented by an introduction and a conclusion written by the editors. Chapters 2, 3, and 8 take an Africa-wide perspective, discussing the evolution of African seaports from the 1840 s to the present and the relationship of African countries with their global trade partners. Chapter 4, 5, 6, and 7 are regional studies on Northern, Western, Eastern, and Southern Africa.

Chapter 2, by Guy Saupin, describes port infrastructure during the precolonial era, specifically from the mid-1840s to the 1880s. Here the author skillfully analyzes the impact on African port cities of three key events of this period: the abolition of the slave trade and the transition to commodity exports, the introduction of steam shipping, and the establishment of formal colonial rule.

In chapter 3, Daniel Castillo Hidalgo and César Ducruet extend the analysis of seaports from the 1880s to the present. The novelty of their work lies in providing one of the few longterm studies of port evolution in Africa. Their key finding is that the ranking of ports in terms of commercial throughput and shipping traffic is very persistent over time. The main ports built during the colonial period still account for most trade today, suggesting another legacy of colonial rule. This chapter builds on an impressive ongoing data collection effort on port statistics from primary and secondary sources (Afriports, African Ports Historical Database, 1880-2010s). I look forward to the online publication of these data, which will for sure prove to be very useful to scholars interested in African trade and development.

Chapter 4, by Miguel Suárez Bosa, provides a case study on North Africa's port development focusing on French and Spanish Morocco between 1912 and 1956. This analysis illuminates how differences in policies among colonial powers affected port expansion, echoing the literature on the identity of the colonizer. The focus on North Africa is also noteworthy, as many works in African economic history tend to privilege the Sub-Saharan part of the continent.

In chapter 5, Edmund Chilaka and Ayodeji Olukoju focus on West Africa, analyzing the evolution of ports in the Gulf of Guinea. After a relatively short sub-section about colonial rule, they carefully examine how port policies, inland transportation infrastructures, global economic cycles, and sociopolitical constraints (such as civil wars) have affected the development of West African ports since 1970.

Chapter 6, by Lourdes Trujillo, Ivone Pérez and Casiano Manrique-de-Lara-Peñate, analyzes the performance of East African ports in recent years. To do so, the authors present an interesting methodology based on indicators of port efficiency and connectivity. Their findings highlight the significance of institutions and port reforms as determinants of port effectiveness.

In chapter 7, Theo Notteboom and Darren Fraser examine the relationship between inland transports and port development and competition in Southern Africa from the mid-1980s to the present. This assessment presents a fascinating case study of a region characterized by a more developed inland transport infrastructure than other areas of Africa, offering new insights into the interaction between internal and external transportation networks.

Chapter 8, by César Ducruet and Kenmei Tsubota, analyzes the evolution of trade flows between Africa and the other world regions using a global perspective, with a particular focus on Asia. The authors highlight how Africa's share in the world trade increased from the $19^{\text {th }}$ century until around 1950 , and then declined in the second half of the $20^{\text {th }}$ century. Moreover, they find that European countries have always been the main destination of African exports, but since the early $20^{\text {th }}$ century, trade partially shifted towards non-European markets.

The final chapter (9), by the editors, draws some general conclusions, nicely linking together the insights emerging in the previous essays. They discuss the role of geography, technology, and institutions in the development of African ports and suggest interesting directions for future research that will certainly stimulate scholars in the field.

Overall, complementing and extending the pioneering work on the same topic edited more than fifty years ago by Brian Hoyle and David Hilling (1970), the book fills several gaps in terms of time and regional coverage. In particular, it extends the analysis of African ports to the post-1970 period and enlarges the scope for comparative analyses by including new case studies. As the editors themselves acknowledge ( $\mathrm{p}$. 219), like in many similar books, there remain inevitable gaps 
in terms of coverage of African regions and periods. For example, the analysis of North Africa is limited to Morocco during the colonial era, while the studies on Western, Eastern, and Southern Africa mostly focus on the post- 1970 period or the most recent decades. Nevertheless, thanks to the description of the historical evolution of African ports provided in the initial chapters, the book retains unity and coherence.

Although the chapters differ in terms of the specific research question that they address (which is not necessarily a bad thing, as it makes the book appealing to a range of different readers), several fascinating unifying themes emerge throughout the book. Particularly interesting is the finding related to the persistence of port hierarchies over time, in a process of path dependence which can contribute to explaining current patterns of regional inequalities in the African continent. The interplay of geographical, historical, and institutional factors in determining the location and structure of port networks also transpires across all regional studies. The debate on the impact of ports on African economic development is also a topic with which, directly or indirectly, all chapters engage.

Combining primary research, impressive data collection efforts, and thoughtful analysis of the secondary literature, the book is a well-thought coordination effort that brought together scholars from different disciplines, such as geography, history, and economics. The contribution to the book of African researchers is worthwhile mentioning. One of the editors, Ayodeji Olukoju, is in fact Professor at the University of Lagos, and one of the chapters is based on research by African academics. Way too often, African economic history is written by researchers working in European universities, limiting methodological and epistemological diversity (Fourie, 2019).

\section{Bibliography}

Fourie, J. (2019). “Who Writes African Economic History?”, Economic History of Developing Regions, 34 (2), 111-131.

Hoyle, B. S. and Hilling, D. (eds.) (1970). Seaports and Development in Tropical Africa. London: Palgrave Macmillan.

Jerven, M. (2011). "The quest for the African dummy: explaining African post-colonial economic performance revisited", Journal of International Development, 23 (2), 288-307.

Federico Tadei University of Barcelona

https://doi.org/10.33231/j.ihe.2021.09.003 